CASSOWARY volume 4 (1): 112-118

ISSN : 2614-8900

E-ISSN : 2622-6545

Program Pascasarjana Universitas Papua, https://pasca.unipa.ac.id/

\title{
Pemanfaatan ampas Sagu sebagai mulsa organik dalam peningkatkan pertumbuhan tanaman Sagu (Metroxylon sagu Rottb.) di lapang
}

\author{
Mikhael Sada ${ }^{1}$, Florentina Heningtyas Listyorini ${ }^{1}$, Barahima Abbas ${ }^{1,2 *}$ \\ ${ }^{1}$ Fakultas Pertanian, Universitas Papua \\ ${ }^{2}$ Program Pascasarjana, Universitas Papua, Jl. Gunung Salju Amban, Manokwari \\ Jalan Gunung Salju Amban, 98314, Manokwari, Papua Barat, Indonesia \\ *Email: barahimabas@gmail.com
}

\begin{abstract}
Sago palm need to be cultivated intensively for increasing carbohydrate resources to anticipate the deficiency of energy sources of the world. This study aims to measure the influences of sago dregs to the sag palm growth in the field. The experimental method used in this works was Randomized Block Design that consisting of five treatments sago dregs weights in the russet stages of sago palm. The composition of the treatment is follows: without sago dregs (P0), $5 \mathrm{~kg}$ sago dregs tree ${ }^{-1}(\mathrm{P} 1), 10 \mathrm{~kg}$ of sago dregs tree $\mathrm{e}^{-1}(\mathrm{P} 2), 15 \mathrm{~kg}$ sago dregs tree $\mathrm{e}^{-1}(\mathrm{P} 3), 20 \mathrm{~kg}$ sago dregs tree $\mathrm{e}^{-1}(\mathrm{P} 4)$. The results showed that sago dregs had a significant effect of the spear leaves growth, but not significantly effect of the plant height growth, number of leaflets growth, and number of leaflets. Utilization of $10 \mathrm{~kg}$ sago dregs tree ${ }^{-1}$ as mulch was calculated influence of the spear leaf growth and utilization of $20 \mathrm{~kg}$ sago dregs as mulch inhibitory of sago palm growth.
\end{abstract}

Keywords: sago dregs, mulch, growth, sago palm

\section{PENDAHULUAN}

Tanaman sagu dapat tumbuh dan beradaptasi pada lahan marginal seperti tanah gambut, tanah masam, air payau, dan area yang kandungan airnya banyak yang tidak memungkinkan tanaman lain dapat tumbuh (Yamamoto, 2015). Tanaman sagu tumbuh dan berkembang dengan baik di lahan mineral dan pertumbuhannya jauh lebih baik dibanding pada lahan rawa atau gambut (Ehara et al., 2015). Berdasarkan penelitian sebelumnya yang dilakukan oleh Craun Resarch selama 10 tahun terakhir menunjukan bahwa sagu dapat tumbuh pada lahan basa termasuk rawa dan gambut. Selama periode lima belas tahun diamati hanya terdapat $4 \%$ sagu pada lahan gambut dangkal yang dapat tumbuh dengan baik. Pertumbuhan tanaman sagu pada lahan gambut dengan kedalaman lebih 2,5 m mengalami pertumbuhan yang baik pada stadia raset , tetapi pertumbuhan terhambat pada stadia pertumbuhan batang dan hasil patinya rendah (Yusup et al., 2015).

Jenis tanaman sagu yang dilaporkan tumbuh di Papua sekitar 60 jenis (Haska, 2015). Pemanfaatan sagu diharapkan meningkat dimasa mendatang dan investor tertarik untuk memanfaatkan sagu sebagai komoditas bisnis yang menguntungkan. Sagu tidak hanya dijadikan sebagai komoditas pangan saja tetapi juga menjadi bahan baku industri dan energi (Haska, 2015). Sagu per 
pohon dapat menghasilkan $200-400 \mathrm{~kg}$ pati kering tergantung dari jenisnya. Keragaman hayati tanaman sagu di Propinsi Papua dan Papua Barat besar (Bintoro et al., 2015). Sagu di daerah Papua memiliki keragaman genetik yang tinggi sehingga perlu diamankan dari erosi genetik serta perlu tindakan pelestarian genetik (Abbas, 2018).

Papua memiliki berbagai varietas sagu berdasarkan karakter morfologi dan genetiknya. Matanubun (2015) melaporkan bahwa 4 hingga 5 varietas lokal ditemukan di Waropen, 6 varietas di Sarmi, 2 varietas di Agats, 10 varietas di Pulau Salawati (Sorong), 17 varietas di pulau Biak, 1 varietas di Timika (Mimika), 14 varietas di Wasior (Teluk Wondama), 9 varietas di Inanwatan (Sorong Selatan), 3 varietas di Onggari (Merauke), 35 varietas di Sentani (Jayapura), 11 varietas di Kaureh (Jayapura), 5 varietas di Windesi (Teluk Wondama), dan 5 varietas di Kais (Sorong Selatan). Secara genetik berdasarkan berbagai marker molekuler seperti RAPD juga dilaporkan eragaman tanaman sagu tinggi (Abbas et al. 2009), berdasarkan marker cpDNA dilaporkan juga bervariasi, berdasarkan gen spesifik gen waxy juga beragam (Abbas and Ehara 2012), intra species juga dilaporkan berbeda berdasarkan penanda gen matK (Abbas et al 2020 ), dan tanaman sagu bervariasi beradasrkan marker gen Nad2 (Abbas et al. 2019).

Sagu merupakan salah satu sumber pangan penghasil karbohidrat potensial di Indonesia yang perlu mendapat perhatian. Saat ini pemanfaatan pati sagu belum optimal yaitu hanya $5 \%$ dari potensi yang ada. Potensi sumber daya yang dimiliki pohon sagu perlu digali dan dimanfaatkan sepenuhnya untuk kesejahteraan masyarakat. Pemuliaan tanaman sagu mestinya diarahkan untuk menghasilkan bibit sagu yang selain memiliki pati tinggi, juga memiliki diameter empulur besar, tidak berduri dan memiliki cita rasa pati yang enak. Namun, sampai saat ini riset mengenai sagu di Indonesia masih sangat terbatas, sehingga pemuliaan sagu untuk menghasilkan bibit unggul demikian akan memerlukan waktu lama, oleh karena itu pemanfaatan sumber daya sagu perlu dilakukan secara bijak dan berkelanjutan sehingga manfaatnya dapat dirasakan secara berkelanjutan oleh masyarakat (Abbas, 2018; Abbas et al. 2020 ${ }^{\mathrm{b}}$. Budidaya tanaman sagu secara baik dapat meningkatkan pendapatan dan ketahanan pangan masyarakat, sehingga teknik budidaya yang dapat mendorong pertumbuhan dan produksi secara maksimal perlu dikaji.

\section{BAHAN DAN METODE}

Bahan yang digunakan pada penelitian ini yaitu bibit sagu umur 8 bulan yang sudah ditanam di lapang yang diberi perlakuan ampas sagu sebagai mulsa organik. Metode yang digunakan dalam penelitian ini adalah metode eksperimen menggunakan Rancangan Acak Kelompok yang terdiri dari lima perlakuan bobot mulsa dan lima ulangan, sehingga diperoleh 25 satuan percobaan. Perlakuan mulsa organic ampas sagu yang digunakan adalah: tanpa mulsa ampas sagu (P0), $5 \mathrm{~kg}$ mulsa ampas sagu per pohon (P1), $10 \mathrm{~kg}$ mulsa ampas sagu per pohon (P2), $15 \mathrm{~kg}$ mulsa ampas sagu per pohon (P3), dan $20 \mathrm{~kg}$ mulsa ampas sagu per pohon $(\mathrm{P} 4)$.

Pengamatan dilakukan terhadap 5 tanaman contoh yang sudah dipilih secara acak. Variabel yang diamati adalah pertumbuhan tanaman sagu yang meliputi tinggi tanaman, jumlah pelepah, jumlah anak daun, dan waktu muncul daun tombak sampai membentuk daun sempurna. Analisis data dilakukan secara statistik dengan menggunakan analisis ragam (ANOVA) untuk melihat pengaruh perlakuan. Apabila 
berpengaruh nyata dilanjutkan dengan uji BNJ dengan taraf kepercayaan $95 \%$.

\section{HASIL DAN PEMBAHASAN}

Hasil analisis ragam menunjukkan bahwa perlakuan ampas sagu sebagai mulsa organik pada berbagai tingkat dosis tidak berpengaruh nyata terhadap tinggi tanaman sagu pada stadia russet. Rata-rata hasil pengamatan tinggi tanaman sagu akibat pemberian berbagai tingkat ukuran berat mulsa ampas sagu disajikan pada Tabel 1.

Perlakuan mulsa ampas sagu dengan berat $10 \mathrm{~kg}$ per pohon cenderung memberikan respon tertinggi sampai dengan umur 20 MST. Tinggi tajuk tanaman sagu mencapai $169.24 \mathrm{~cm}$ pada umur 20 MST. Pada umur 24 MST dan 28 MST tanaman yang tidak diberi mulsa ampas sagu memberikan respon tinggi yang baik terhadap tanaman sagu. Pemberian mulsa ampas sagu dengan dosis $5 \mathrm{~kg}$ per pohon, 10 kgperpohon, dan 15 kgperpohon cenderung memberikan hasil pertambahan tinggi yang berbeda pada umur 8-28 MST. Hal ini di sebabkan karena pengukuran dilakukan pada setiap tajuk baru yang muncul. Pengukuran dilakukan dari permukaan mulsa ampas sagu sampai ujung tajuk tertinggi. Setiap tajuk yang terbentuk mempunyai panjang yang berbeda.

Hasil analisis ragam menunjukkan bahwa pemberian ampas sagu sebagai mulsa organik pada berbagai ukuran berat tidak berpengaruh nyata terhadap jumlah pelepah sagu. Rata-rata hasil pengamatan jumlah pelepah sagu akibat pemberian berbagai ukuran beratmulsa ampas sagu disajikan pada Tabel 2. Data tersebut menunjukkan bahwa perlakuan ampas sagu dengan berbagai ukuran berat tidak memberikan pengaruh terhadap jumlah pelepah.

Hasil analisis ragam menunjukkan bahwa pemberian ampas sagu sebagai mulsa organik tidak berpengaruh nyata terhadap jumlah anak daun sagu. Ratarata hasil pengamatan jumlah anak daun sagu akibat pemberian berbagai ukuran berat ampas sagu disajikan pada Tabel 3.

Tabel 1. Rata-rata tinggi tanaman sagu $(\mathrm{cm})$ umur 4-28 MST pada berbagai ukuran berat ampas sagu

\begin{tabular}{cccccccc}
\hline Ukuran Berat & \multicolumn{7}{c}{ Umur (MST) } \\
\cline { 2 - 8 } Ampas Sagu & 4 & 8 & 12 & 16 & 20 & 24 & 28 \\
\hline 0 kg per pohon & 134.02 & 143.56 & 149.32 & 151.34 & 158.26 & 175.02 & 182.42 \\
$5 \mathrm{~kg}$ per pohon & 142.64 & 147.60 & 159.52 & 156.30 & 149.88 & 170.42 & 179.26 \\
$10 \mathrm{~kg}$ per pohon & 150.82 & 155.94 & 160.70 & 165.72 & 169.24 & 174.14 & 17 \\
$15 \mathrm{~kg}$ per pohon & 146.46 & 150.76 & 149.90 & 158.10 & 163.38 & 166.86 & 171.68 \\
$20 \mathrm{~kg}$ per pohon & 135.24 & 143.40 & 148.36 & 152.32 & 158.20 & 168.48 & 178.46 \\
\hline
\end{tabular}

Tabel 2. Rata-rata jumlah pelepah sagu umur 4-28 MST pada berbagai ukuran berat ampas sagu

\begin{tabular}{lllrrrrr}
\hline \multicolumn{1}{c}{ Ukuran Berat } & \multicolumn{7}{c}{ Umur (MST) } \\
\cline { 2 - 8 } Ampas Sagu & \multicolumn{1}{c}{4} & \multicolumn{1}{c}{12} & 16 & 20 & 24 & 28 \\
\hline 0 kg per pohon & 9.4 & 10.2 & 11.2 & 12.0 & 12.6 & 13.6 & 14.4 \\
$5 \mathrm{~kg}$ per pohon & 8.2 & 9.2 & 10.0 & 10.6 & 11.4 & 12.2 & 13.0 \\
$10 \mathrm{~kg}$ per pohon & 9.6 & 9.6 & 10.4 & 11.0 & 11.6 & 12.4 & 13.6 \\
$15 \mathrm{~kg}$ per pohon & 10.2 & 11.0 & 11.8 & 11.8 & 12.8 & 13.6 & 14.6 \\
$20 \mathrm{~kg}$ per pohon & 8.8 & 9.8 & 10.2 & 11.0 & 11.8 & 12.6 & 13.4 \\
\hline
\end{tabular}


Perlakuan mulsa ampas sagu dengan berbagai ukuran berat tidak memberikan pengaruh yang nyata terhadap jumlah anak daun. Pada umur 4 dan 16 MST mulsa ampas sagu dengan dosis $20 \mathrm{~kg}$ perpohon cenderung memberikan respon tertinggi terhadap jumlah anak daun.

Hasil analisis ragam menunjukkan bahwa pemberian ampas sagu sebagai mulsa organik pada berbagai ukuran berat berpengaruh nyata terhadap waktu muncul daun tombak ke 2 sampai membentuk daun sempurna. Rata-rata hasil pengamatan waktu muncul daun tombak sampai membentuk daun sempurna akibat pemberian berbagai ukuran beratmulsa ampas sagu disajikan pada Tabel 4.

Ampas sagu $10 \mathrm{~kg}$ per pohon memberikan hasil yang nyata terhadap munculnya daun tombak ke 2 dibandingkan dengan perlakuan yang lain. Hal ini menunjukkan bahwa dosis mulsa ampas sagu $10 \mathrm{~kg}$ per pohon dapat mempercepat waktu muncul daun tombak sampai membentuk daun sempurna kemudian muncul daun tombak yang baru. Peningkatan tersebut diduga karena ampas sagu telah terdekomposisi dan mampu menyediakan unsur hara yang cukup. Fenomena tersebut menyerupai dengan yang dilaporkan oleh Wahida dan Limbongan (2015) bahwa ampas sagu merupakan limbah organik yang sangat reaktif terhadap senyawa bioaktifator sebagai bahan utama pembuatan kompos dan merupakan salah satu cara alternatif untuk mengurangi tumpukan ampas sagu yang tidak terolah dan mengurangi pencemaran lingkungan. Selanjutnya Syakir et al. (2009) mengungkapkan bahwa ampas sagu berpotensi sebagai sumber bahan organik untuk meningkatkan kesuburan tanah.

Tabel 3. Rata-rata jumlah anak daun sagu umur 4-28 MST pada berbagai tingkat dosis mulsa ampas sagu. Pengukuran dilakukan pada pelepah terakhir muncul

\begin{tabular}{crrrrrrr}
\hline Ukuran Berat & \multicolumn{7}{c}{ Umur (MST) } \\
\cline { 2 - 8 } Ampas Sagu & 4 & 8 & 12 & 16 & 20 & 24 & 28 \\
\hline 0 kg per pohon & 37.8 & 39.2 & 39.2 & 39.2 & 42.6 & 43.4 & 43.4 \\
5 kg per pohon & 37.2 & 37.2 & 37.8 & 37.2 & 39.2 & 39.4 & 41.0 \\
10 kg per pohon & 36.0 & 36.0 & 36.0 & 36.6 & 38.8 & 38.8 & 40.2 \\
$15 \mathrm{~kg}$ per pohon & 37.0 & 37.0 & 37.6 & 37.4 & 38.4 & 38.6 & 38.8 \\
20 kg per pohon & 38.2 & 38.2 & 38.2 & 40.2 & 41.2 & 42.2 & 42.2 \\
\hline
\end{tabular}

Tabel 4. Rata-rata waktu muncul daun tombak sampai membentuk daun sempurna pada berbagai ukuran berat mulsa ampas sagu. Pengukuran dilakukan pada daun tombak yang secara berurutan muncul saat pengamatan

\begin{tabular}{lccrrrrc}
\hline Ukuran Berat & \multicolumn{7}{c}{ Daun Tombak } \\
\cline { 2 - 8 } \multicolumn{1}{c}{ Ampas Sagu } & \multicolumn{1}{c}{2} & \multicolumn{1}{c}{2} & 3 & 4 & 5 & 6 & 7 \\
\hline 0 kg per pohon & 0.0 & $33.0 \mathrm{ab}$ & 68.2 & 89.2 & 111.6 & 145.2 & 164.8 \\
5 kg per pohon & 4.4 & $34.6 \mathrm{ab}$ & 65.4 & 85.0 & 114.4 & 138.2 & 178.8 \\
10 kg per pohon & 7.4 & $14.6 \mathrm{~b}$ & 69.6 & 93.4 & 114.4 & 139.6 & 173.2 \\
15 kg per pohon & 7.4 & $31.8 \mathrm{~b}$ & 59.8 & 69.6 & 113.0 & 149.4 & 163.4 \\
20 kg per pohon & 0.0 & $44.4 \mathrm{a}$ & 62.6 & 96.2 & 129.8 & 148.0 & 176.0 \\
\hline
\end{tabular}

BNJ 0,05 16.80

Keterangan : Angka-angka pada kolom yang diikuti dengan huruf yang sama tidak berbeda nyata menurut uji BNJ pada taraf kepercayaan $95 \%$. 
Pengaruh ampas sagu terhadap kesuburan tanah ditentukan oleh tingkat dekomposisi dan komposisinya. Limbah yang belum terdekomposisi secara baik akan mengandung $\mathrm{C} / \mathrm{N}$ dan asam fenolat yang tinggi sehingga dapat menghambat pertumbuhan tanaman. Tingginya nisbah $\mathrm{C} / \mathrm{N}$ akan menyebabkan tanaman kekurangan $\mathrm{N}$ karena immobilisasi. Sedangkan limbah yang telah terdekomposisi dapat berfungsi sebagai amelioran yang berfungsi meningkatkan pertumbuhan dan produksi tanaman (Syakir et al. 2008). Sangadji et al. (2008) melaporkan bahwa ampas sagu memiliki kandungan nutrisi berupa protein kasar, bahan kering, ADF, VDF, dan lignin yang tinggi dan dapat menjadi racun oleh karena itu perlu di olah untuk menurunkan kandungan ligninselulosa yang tinggi sehingga aman untuk dimanfaatkan sebagai bahan organik. Ampas sagu mengandung $86.0 \%$ bahan kering, $2.1 \%$ protein kasar, $1.8 \%$ lemak kasar, $20.3 \%$ serat kasar, $4.6 \%$ abu, $63.8 \%$ NDF, $49 \%$ ADF, $36.3 \%$ selulosa, $14.6 \%$ hemiselulosa, $9.7 \%$ lignin, dan $3,3 \%$ silica (Sangadji 2009).

\section{KESIMPULAN}

Berdasrkan pengukuran dan pengamatan serta analisis data yang cermat dari penelitian yang telah dilakukan, maka disimpulkan Pemberian mulsa ampas sagu dapat mempercepat munculnya daun tombak sampai membentuk daun sempurna namun tidak menginduksi pertumbuhan tinggi tajuk tanaman, jumlah pelepah, dan jumlah anak daun. Ampas sagu $10 \mathrm{~kg}$ per pohon memberikan respon yang nyata terhadap munculnya daun tombak ke 2. Mulsa ampas sagu dengan dosis $20 \mathrm{~kg}$ per pohon memberikan respon yang lambat terhadap waktu muncul daun tombak.

\section{DAFTAR PUSTAKA}

Abbas B, Bintoro MH, Sudarosono, Surahman M, Ehara H. 2009. Genetic relationship of sago palm (Metroxylon sagu Rottb.) in Indonesia based on RAPD markers. Biodiversitas 10 (4): 168174.

DOI:

10.13057/biodiv/d100402

Abbas B, Renwarin Y, Bintoro MH, Sudarsono, Surahman M, Ehara H. 2010. Genetic Diversity of Sago Palm in Indonesia Based on Chloroplast DNA (CpDNA) Markers. Biodiversitas 11 (3): 112-17. DOI: 10.13057/biodiv/d110302.

Abbas B, Tjolli I, Dailami M, Munarti. 2019. Phylogenetic of sago palm (Metroxylon sagu) and others monocotyledon based on mitochondrial Nad2 gene markers. Biodiversitas 20 (8): 2249-2256. DOI: 10.13057/biodiv/d200820.

Abbas, B dan H. Ehara. 2012. Assessment genetic variation and relationship of sago palm (Metroxylon sagu Rottb.) in Indonesia based on specific expression gene (Wx genes) markers. African Journal of Plant Science. 6(12):314-320

Abbas B. 2018. Sago palm genetic resource diversity in Indonesia. In: Ehara H, Toyoda Y, Johnson D (eds.). Sago Palm: Multiple Contributions to Food Security and Sustainable Livelihoods. Springer, Singapore. DOI: 10.1007/978981-10-5269-95.

Abbas B, Tjolli I, Munarti. 2020 ${ }^{\mathrm{b}}$. Genetic diversity of sago palm (Metroxylon sagu) accessions based on plastid cpDNA matK gene as DNA barcoding. Biodiversitas 21: 219-225.Abbas B, R. J. Kabes, I. Tjolli, K. Wibowo, N. Richana. 2020 
Feasibility study penerapan hasil riset berbasis sagu. Program Pascasarjana UNIPA, 106p.

Abbas, B., F. H. Listyorini and Munarti. 2015. Genetic Diversity of Eleven Sago Palm Accessions from SRC's Germ Plasm Based on Mitochondrial atp6-2 Genes and Introns. (UNIPA). Proceedings of the 12th International Sago Symposium. pp 82-87.

Bintoro, H. M. H., S. Amarillis and R. K. Dewi. 2015. Sago Palm Development in Papua and West Papua Provinces, Indonesia. Department of Agronomy and Horticulture Faculty of Agriculture Bogor Agricultural University. Department of Agronomy and Horticulture Faculty of Agriculture Bogor Agricultural University. IPB's Vocational School Kampus Program diploma IPB. Proceedings of the 12th International Sago Symposium. pp 73-77.

Ehara, H., H. Naito, T. Mishima and C. Mizota. 2015. Genetic Variation and Agronomic Features of Metroxylon Palms in Asia and Pacific. International Cooperation Center for Agricultural Education, Nagoya University. College of Life Sciences, Kurashiki University of Science and The Arts. Graduate School of Regional Innovation Studies, Mie University. Faculty of Agriculture, Iwate University. Proceedings of the 12th International Sago Symposium. pp 10-15

Haska, N. 2015. Conversion of Natural Sago to Sago Plantation Based on Natural Resources Sustainability and Biodiversity of Sago in Papua, Indonesia. Biotechnology Center of the Agency for the Assessment and Application of Technology (BPPT). Proceedings of the 12th International Sago Symposium. pp 26-30.

Matanubun, H. 2015. Folk Taxonomy of Sago Palm Varieties Around Lake Sentani, Jayapura, Papua Province, Indonesia. Tuber Crops and Sago Research Center, the University of Papua, Proceedings of the 12th International Sago Symposium. pp 114-116.

Sangadji, I. 2009. Mengoptimalkan Pemanfaatan Ampas Sagu Sebagai Pakan Ruminansia Melalui Biofermentasi Dengan Jamur Tiram (Pleurotus ostreatus) Dan Amoniasi. Sekolah Pascasarjan Institut Pertanian Bogor.

Sangadji, I., A. Prakkasi, K. G. Wiryawan dan B. Haryanto. 2008. Perubahan Nilai Nutrisi Ampas Sagu selam pada Fase Pertumbuhan Jamur Tiram Putih (Pleurotus ostreatus) yang berbeda. Jurusan Peternakan Fakultas Pertanian Universitas Pattimura Ambon. Departemen Ilmu Nutrisi dan Teknologi Pakan, Fakultas Peternakan,IPB. Balai Penelitian Ternak, Pajajaran Bogor. Jurnal Ilmu Ternak 8 (1) : 31-34.

Syakir, M., M. H. Bintoro, dan H. Agusta. 2009. Pengaruh Ampas Sagu Dan Kompos Terhadap Produktivitas Lada Perdu. Balai Penelitian Tanaman Obat dan Aromatik. Institut Pertanian Bogor, Kampus IPB Darmaga Bogor. Jurnal Litri 15 (4) :168173.

Syakir. M., M.H. Bintoro, H. Agusta, dan Hermanto. 2008. Pemanfaatan Limbah Sagu Sebagai Pengendalian Gulma Pada Lada Perdu. Balai Penelitian Tanaman Obat Dan Aromatik. Institut 
Pertanian Bogor. Jurnal Littri 14 (3) : $107-112$.

Wahida dan Limbongan, A. A. 2015. Pemanfaatan Ampas Sagu Sebagai Bahan Dasar Kompos Pada Beberapa Dosis Pencampuran Dengan Kotoran Sapi. Jurusan Teknik Pertanian FAPERTA UNMUS. Jurusan Agroteknologi FAPERTA UNMUS. Agricola 5 (1) : 1-8.
Yamamoto, Y. 2015. Matter Production as a Basis of Starch Production in Sago Palm (Metroxylon sagu Rottb.). Former Faculty of Agriculture, Kochi Univers. Proceedings of the 12th International Sago Symposium. Japan. pp 1-5.

Yusup, S., Y. C. M. Roland, Z. Fariza, B. Noraini and P. Zahri. 2015. Suitability of Peat Swamp Areas for Commercial Production of Sago Crop-Sarawak Experience. CRAUN Research Sdn. Bhd. Proceedings of the 12th International Sago Symposium. pp $35-45$. 